IRA-International Journal of Management \&

Social Sciences

ISSN 2455-2267; Vol.08, Issue 03 (September 2017)

Pg. no. 248-255

Institute of Research Advances

http://research-advances.org/index.php/RAJMSS

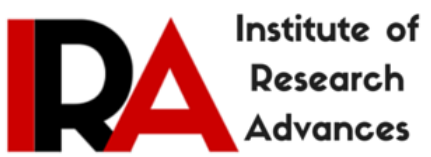

\title{
Quality Control through Peer Review Process in Scholarly Communication: Review of Related Literature
}

\author{
Vishnu Kumar Gupta \\ ORCID: http://orcid.org/0000-0003-4579-7132 \\ Librarian, Dept. of Bioscience and Biotechnology Library \\ Banasthali University (Rajasthan)- 304022, India.
}

Type of Review: Peer Reviewed.

DOI: http://dx.doi.org/10.21013/jmss.v8.n3.p3

\section{How to cite this paper:}

Gupta, V.K. (2017). Quality Control through Peer Review Process in Scholarly Communication: Review of Related Literature. IRA-International Journal of Management \& Social Sciences (ISSN 2455-2267), 8(3), 248-255. doi:http://dx.doi.org/10.21013/jmss.v8.n3.p3

(C) Institute of Research Advances.

\section{(cc) BY-NO}

This work is licensed under a Creative Commons Attribution-Non Commercial 4.0 International License subject to proper citation to the publication source of the work.

Disclaimer: The scholarly papers as reviewed and published by the Institute of Research Advances (IRA) are the views and opinions of their respective authors and are not the views or opinions of the IRA. The IRA disclaims of any harm or loss caused due to the published content to any party.

Institute of Research Advances is an institutional publisher member of Publishers Inter Linking Association Inc. (PILA-CrossRef), USA. The institute is an institutional signatory to the Budapest Open Access Initiative, Hungary advocating the open access of scientific and scholarly knowledge. The Institute is a registered content provider under Open Access Initiative Protocol for Metadata Harvesting (OAI-PMH).

The journal is indexed \& included in WorldCat Discovery Service (USA), CrossRef Metadata Search (USA), WorldCat (USA), OCLC (USA), Open J-Gate (India), EZB (Germany) Scilit (Switzerland), Airiti (China), Bielefeld Academic Search Engine (BASE) of Bielefeld University, Germany, PKP Index of Simon Fraser University, Canada. 


\begin{abstract}
This review of related literature on the theme of peer review process in scholarly communication explains the status of research on periodicals, grant peer review and fellowships. The paper highlights the quality related issues of the scholarly communication and peer review process. Peer reviewers are invited to grant applications or assess fellowship or review manuscript in a peer review process undertake the responsibility for confirming top-level quality and standards in their concerned subject fields.
\end{abstract}

Keywords- Peer Review, Scholarly Communication, Quality Control.

\title{
1. Introduction
}

Peer review process is the fundamental mechanism in the scholarly communication to maintain the quality of research in almost every academic discipline. In terms of quality of research, peer review decides which research findings are published and which research grants funding. Research evaluation systems in many countries are generally based on peer review, for example- the British research assessment exercise.

In 1991, Joshua Lederberg, the Nobel laureate geneticist and former president of Rockefeller University, delivered a speech, entitled "Communication as the Root of Scientific Progress." In his speech, he focussed on the relevance of scholarly communication, scholarly literature, and scholarly publishing for the development of science.

\section{Scholarly Communication}

Generally, the word "scholarly" is applied in the academia, especially in higher education, for works that involve research and/or investigation. Scholarly communication is simply used to describe how research results are disseminated among peers. Research scholars and academicians communicate knowledge to audiences in formal channels of communication in the form books, journals, proceedings, etc., and discuss and share ideas in informal communication activities through conversations, talks, electronic mails, telephone calls, letters and so on. Scholarly communication is concerned with, according to Borgman (1990), "using and disseminating information in academic fields through formal and informal channels."2

There are many authentic and standard definitions of "scholarly communication"; few of them are presented in subsequent paragraphs.

Lyman and Chodorow (1998) assume that scholarly communication emerged when Information and Communication Technology (ICT) became more significant in scholarly research. They think that scholarly communication is a term "invented to frame both print publication and digital communication within a single functional schema."

Borgman (2000) succinctly defines scholarly communication as "the study of how scholars in any field (e.g. physical, biological, social and behavioural sciences, humanities and technology) use and disseminate information through formal and informal channels. The study of scholarly communication includes the growth of scholarly information, the relationships among research areas and disciplines, the information needs and uses of individual user groups, and the relationships among formal and informal methods of communication." 4

Association of College and Research Libraries, a division of the American Library Association, (2004) describes scholarly communication as "the system through which research and other scholarly writings are created, evaluated for quality, disseminated to the scholarly community, and preserved for future use. The system includes both formal means of communication, such as publication in peer-reviewed journals, and informal channels, such as electronic listservs."

University College London states that, "scholarly communication is the method and route by which academic information is passed from author to reader, via various intermediaries such as libraries and publishers." examples of formal scholarly communications are monographs, edited books, research papers, conference proceedings, letters, technical reports, memos, and so on. These all are public and permanent vehicles for scholarly communications ${ }^{7}$ (Mukherjee, 2009). 
Rowlands, Nichols, \& Huntington (2004) like to include in scholarly communication "only the peer-reviewed literature published upon completion of research." $"$ On the other hand, a broader definition of scholarly communication contains all communication among peers ${ }^{9}$ (Harnad, 1995).

Whether scientific, technical, or literary, scholarly communication must be appropriated within the wider context of periodical history and the larger context of the reading audience, whether a sophisticated and initiated reader or an educated lay public. The historical aspect of scientific periodical indicates complex admixtures of evolutionary progress, interconnecting history of printing, emerging scientific fields, economics of publishing, and professional life of scientists.

\section{Peer Review Process}

In the mid-eighteenth century, which is referred to as the starting of peer reviewing, the Royal Society in London took over "fiscal responsibility for the journal Philosophical Transactions and established what they called a Committee on Papers. "10

In the words of Blaise Cronin (2005), peer review is "the instrument for ensuring trustworthiness." ${ }^{11}$ While, Ziman (2000) feels that "peer review grounds all scholarship." 12 Peer reviewers examine the "flow of ideas through the various gates of the academic community"13, according to Lamont (2009). Journal peer review motivates the scholarship, considering the view, in 2008 Alberts, Hanson, \& Kelner (p. 15) write as "the Intergovernmental Panel on Climate Change and other similar advisory groups base their judgments on peerreviewed literature, and this is part of their success. Many legal decisions and regulations also depend on peerreviewed science.", 14

Thus, assessment by peer reviewers in research demands a course of action by which a 'jury of equals' work in a given academic field convenes to assess the work of academic activity or its consequences, such as, manuscripts for publication and applications for research fellowships and grants. This type of 'jury of equals' could be referred to as individually or a group, without the requirement of personal links among the evaluators. The peer review process lets the "active producers of science, the experts, become the gatekeepers of science." "By using the judgment and opinions of peers and members of the 'community of science,' the process of peer review is aimed at keeping the review 'in the family""16 (Geisler, 2000, pp. 218-219). Notwithstanding, keeping it 'in the family' may result in intellectual closed-mindedness.

Peer reviewers are invited or hired to grant applications or assess fellowship or manuscripts in a peer review process undertake the responsibility for confirming top-level quality and standards in their concerned subject domains. However, peer reviewers active in the same domain may be unperceptive of different approaches, they "are said to be in the best position to know whether quality standards have been met and a contribution to knowledge made"17 (Eisenhart, 2002, p. 241). In social psychology, Krampen \& Montada (2002) conceptualized the peer review process as "a social judgment process of individuals in a small group.",

\subsection{Quality Control through Peer Review}

In peer review process, "the reliability, fairness, and predictive validity of the process are the three quality parameters for professional evaluations"60 (Bornmann, 2011). For developing reliable and valid knowledge, quality control promised by subject specialists in the established peer review of manuscript for scientific periodicals is indispensable in almost every academic disciplines ${ }^{19}$ (Hemlin \& Rasmussen, 2006). The most concurrent usability of peer review in scholarly communication is for the selection of fellowship and grant applications, in addition to choosing the manuscripts for publication in academic periodicals.

According to the results of Wessely and Wood's study (1999), "the peer review of grant proposals may be more relevant than publication practices to the health of science. Good papers will get published somewhere, as will bad ones, whereas applications for grants that do not succeed represent research that no one conducts."20 Guston (2003) realises that "researchers rely less and less on regular research funds from their universities and more on external research grants that are allocated on the basis of peer review."

After the Second World War (at first most probably in the United States) "peer review became the process for allocating research funds" 22 (Biagioli, 2002). Nearly all facets of the traditional scholarly communication depend on the quality estimations by peer reviewers. Such estimations decide, among other things, "who gets tenure, who gets which job, and who gets which honours and awards"23 (Feist, 2006). 
In the process of review of manuscript received for publications and grant proposals for research funding, it is the peer reviewers' job to approve for selection the "best" academic research under the situation of rare and/or less resources, for example- limited funds, and limited space for periodical publications ${ }^{24}$ (Hackett \& Chubin, 2003). "With grants, an applicant submits a proposal, which is then reviewed by peers who make a judgement on its merits and eligibility for funding. With publications, an author submits a paper to a journal or a book proposal to a publisher, and peers are asked to offer a judgement as to whether it should be published"25 (British Academy, 2007, p. 2).

In the process of peer review of academic journals, reviewers requested by the editor(s) generally give an overall publication recommendation along with a written review. "The editor, on the basis of the reviews and his or her own evaluation, decides to reject the submission, seek further review, ask the author to revise the manuscript in response to suggestions by the reviewers and the editor, or accept the manuscript"26 (Jayasinghe, Marsh, \& Bond, 2001, p.344).

Various studies conducted by Bakanic, McPhail, \& Simon ${ }^{27}$ (1987); Bornmann \& Daniel ${ }^{28}$ (2008); Fogg \& Fiske $^{29}$ (1993); Lock ${ }^{30}$ (1985); Petty \& Fleming ${ }^{31}$ (1999); Sternberg, Hojjat, Brigockas, \& Grigorenko ${ }^{32}$ (1997); and Zuckerman \& Merton $^{33}$ (1971) investigating the interrelationship between reviewers' ratings and editors' decisions on submissions at single journals have showed that the reviewers' ratings are highly correlated with the editors' final decisions. This indicates that editors' judgments on manuscript(s) rely on the decisions of the reviewers. Peer review for fellowship(s) presents identical correlations between reviewers' ratings and the decisions of a selection committee ${ }^{34}$ (Bornmann, Mutz, \& Daniel, 2007).

Reviewers can work openly or anonymously. The individuals reviewed may or may not be anonymous, i.e. double-blind versus single-blind peer review. Reviewers may be assigned ad hoc or permanently. After a group of reviewers is assigned, the members may review either independently or collectively ${ }^{16}$ (Geisler, 2000). Funding agencies may appoint reviewers from private industry, government, and/or academia. A single reviewer or a committee may provide a peer review ${ }^{35}$ (Marsh \& Ball, 1991).

The peer review process can make its outcomes public ${ }^{36}$ (Poschl, 2004) or disclose them only to those directly involved. Peer review practices, accordingly, may be described as heterogeneous processes across and among various knowledge fields, funding agencies, journal editors, rating schemas, etc.

The peer review process of BIF fellowship, awarded by the German based international foundation named "Boehringer Ingelheim Fonds" (BIF), which is working for the development of fundamental research in the field of biomedicine, were examined by the Bornmann and Daniel (2005). They revealed that "fellowships were awarded to post-graduate researchers according to the following main criteria:

(i) Scientific quality as demonstrated by the applicant's achievements to date;

(ii) The originality of the proposed research project; and

(iii) The scientific standing of the laboratory where the research will be conducted." 37

In 2008, Bornmann, Nast, and Daniel tested the criteria applied in peer review and carried out a "quantitative content analysis of 46 research studies on editors' and reviewers' criteria for the assessment of manuscripts and their grounds for accepting or rejecting manuscripts. The 572 differing criteria and reasons from the 46 studies could be assigned to nine areas:

(i) Relevance of contribution;

(ii) Writing/presentation;

(iii) Design/conception;

(iv) Method/statistics;

(v) Discussion of results;

(vi) Reference to the literature and documentation;

(vii) Theory; 
(viii) Author's reputation/institutional affiliation; and

(ix) Ethics." 38

The key parameters for reviewers and editors in manuscript's evaluation are associated with the quality of the research underlying a manuscript- design/conception, theory, and discussion of findings. According to the results of a study conducted by Bakanic, McPhail, and Simon ${ }^{39}$ (1989), positively affirmative comments occur far less frequently; while negatively refusal comments outnumber in review documents in the evaluation of manuscripts accepted to the American Sociological Review.

\subsection{Merits of Peer Review}

Supporters of the peer review process discuss that it is more impressive than any other known mechanism for self-regulation in encouraging the critical selection that is so crucial to the emergence of scientific and technological knowledge. Expressing it into a broader sense, as per the Popper's ${ }^{40}$ (1961) "critical rationalism, intellectual life and institutions should be subjected to maximum criticism, in order to counteract and eliminate as much intellectual error as possible" ${ }^{\text {41 }}$ (Bartley, 1984, p. 113).

It is believed that the bogus article by Philip Davis submitted to the open-access journal The Open Information Science Journal which the editor accepted for publication, would have been recommended for rejection if peer reviewers had been concerned ${ }^{42}$ (Editor to quit over hoax open-access paper, 2009). If the editors of the journal 'Social Text' had sent manuscript of Alan D. Sokal, entitled "Transgressing the boundaries: Toward a transformative hermeneutics of quantum gravity" to external peer reviewers, the manuscript would probably have been rejected and the well-known Sokal affair (Sokal, 2008) might not have happened. ${ }^{43}$

Many scholars, like Goodman, Berlin, Fletcher, \& Fletcher (1994), and Pierie, Walvoort, \& Overbeke (1996) prove the belief that peer review enhanced the quality of the recording and disseminating the research outputs. ${ }^{44-}$ ${ }^{45}$ However, options to peer review have been proposed, they have not been executed. Roy (1985), for instance, devised a "Peer-Reviewed Formula System, in which research money is allocated proportional to prior research productivity." 46 This formula is unfavourable to new and younger researchers. Abelson (1980, p. 62), a supporter of peer review, jotted down, "the most important and effective mechanism for attaining good standards of quality in journals is the peer review system." ${ }^{47}$ Journal peer review, in the words of Shatz (2004, p.30), "motivates scholars to produce their best, provides feedback that substantially improves work which is submitted, and enables scholars to identify products they will find worth reading.",48

The supporters of peer review are not the only individuals well-disposed to the process. A sequence of survey studies on journal peer review and grants have written on academicians' high satisfaction with it. Published by Hoffmann, Joye, Kuhn, \& Métral (2002), the Swiss National Science Foundation (SNSF) conducted a survey of researcher scholars at Swiss universities about its grant reviews and resulted that "the evaluation process was regarded as good and its administration efficient." published in Academy of Management Journal and Academy of Management Review agreed that the reviewers' recommended revisions improved their $\operatorname{articles}^{50}$ (Bedeian, 2003). About $97 \%$ of more than a thousand Astronomy \& Astrophysics researchers indicated that "reviewers had dealt competently with their manuscripts" ${ }^{21}$ (Bertout \& Schneider, 2004). Similar findings seen in two surveys of writers for Nature ${ }^{52}$ (2006) and Gibson, Spong, Simonsen, Martin, \& Scott's (2008) Obstetrics \& Gynecology papers. ${ }^{53}$ A survey study of subject reviewers, conducted by the German Research Foundation (DFG), yielded a similar positive result ${ }^{54}$ (Hornbostel \& Olbrecht, 2007). In an international survey, carried out by the United Kingdom's Publishing Research Consortium (2008), on the attitudes and behaviour of 3040 scholars, a large majority (85\%) believed that journal peer review largely helps scientific communication, and "about $83 \%$ agreed that without peer review researcher scholars would have no control over scientific communication."

\subsection{Demerits of Peer Review}

Generally, critics of peer review quote the key findings of the highly influential research paper on grant peer review at the NSF conducted by Cole, Cole, and Simon (1981, p. 885), "the fate of a particular application is roughly half determined by the characteristics of the proposal and the principal investigator, and about half by apparently random elements which might be characterized as 'the luck of the reviewer draw.",56 Young (2003) deeply felt that the one and only reason for "the further implementation of the peer review process- according to its skeptics- is the lack of any clear consensus on a better alternative." ${ }^{, 57}$ Frey $(2003$, p. 206) opines that peer review develops a form of intellectual prostitution, where the scholars are compelled to follow peer reviewers' desires "slavishly.", 
Peer review process is not free from lacunas, and has many drawbacks. Some of them were mentioned by Gupta $^{59}$ (2017), such as, this process is slow and takes too much time; it is not always successful in uncovering academic theft, detecting errors and plagiarism; partiality and biased attitude in reviewers' side may be existed; and it can be unhealthily used by competitors and opponents. Published in 2011 volume of 'Annual Review of Information Science and Technology', Bornmann (2011) extensively reviewed and presented a survey of researches on "peer review processes and the arguments used by proponents and opponents in recent years."60

Given that peer reviewers are normal humans having their own strengths, weaknesses and views; they are not prophets $^{61}$ (Ehses, 2004). Though peer reviewers trust that they select the "best" based on some objective parameters, according to the United States' National Academy of Sciences (2006), "decisions are influenced by factors- including biases about race, sex, geographic location of a university, and age- that have nothing to do with the quality of the person or work being evaluated." ${ }^{2}$. A large number of researches have been carried out to examine the potential sources of bias in peer review.

\section{Peer Review and Reference Accuracy}

The high level of reference accuracy, undoubtedly, makes the scholarly communication more reliable as well as useful, and leads towards the high quality scholarship ${ }^{63}$ (Asano, Mikawa, Nishina, Maekawa, \& Obara, 1995a). The reference errors of the 'Canadian Journal of Anaesthesia' were reduced by 50\% from 1990 to 1994 by demanding the photocopy of the first page of each and every reference cited in the 'Reference Lists $^{\text {,64 }}$ (Asano, Mikawa, Nishina, Maekawa, \& Obara, 1995b).

Idrisa Pandit ${ }^{65}$ (1993) also verified 335 bibliographical references, in which 177 (52.8\%) contained errors in the manuscripts, while only $14(4.2 \%)$ errors were found after publication. The review staff deeply checked the references in the manuscripts before final publication. This shows that peer review process significantly decreased the quantity of reference errors. Accuracy is an important criterion of quality measurement.

In 2010, Onwuegbuzie, Frels, \& Slate conducted a research which is based on mixed research methods. They pin-pointedly examined the 150 article's manuscripts submitted for publication to the journal 'Research in the Schools', and revealed that astonishingly $91.8 \%$, which is a major part of authors, who submit articles to this journal commit citation errors. These 150 article's manuscripts accounted approximately $60 \%$ of total article's manuscripts submitted to this journal over the period of 7 years, i.e. 2003 to 2010. This period was sufficient to make their "findings generalizable to the population of manuscripts submitted to the journal Research in the Schools" $"$ (p. 3).

\section{Conclusion}

Most successful academicians feel the journal peer review to be effective, since it diminish the number of errors in published work. Although, peer review is useful in decision making in promotions, award fellowships, grant money in research projects, and selection of articles for publications, it also enhances the quality of an $\operatorname{article}^{59}$ (Gupta, 2017). The well-qualified subject experts can genuinely evaluate cutting-edge research and development ${ }^{60}$ (Bornmann, 2011). Peer review is need of the hour to improve and maintain the quality of submitted manuscripts, award fellowship, and funding research projects.

\section{Source of Funding}

No external funding was received in support for conducting this study.

\section{References-}

[1] Lederberg, J. (1993). Communication as the root of scientific progress. Current Contents, 1, 5-11.

[2] Borgman, C.L. (1990). Editor's introduction, in Borgman, C.L. (Ed.), Scholarly Communication and Bibliometrics, Sage Publications: Newbury Park, CA, pp. 10-27.

[3] Lyman, P., \& Chodorow, S. (1998). The future of scholarly communication. In, The mirage of continuity: Reconfiguring academic information resources for the 21 st century. Washington, D.C.: CLIR and AAU.

[4] Borgman, C.L. (2000). Digital libraries and continuum of scholarly communication. Journal of Documentation, 56(4), 412-430.

[5] Association of College and Research Libraries (2004). Principles and strategies for the reform of scholarly communication. Retrieved July 10, 2017 http://www.ala.org/ala/acrl/acrlpubs/whitepapers/principlesstrategies.htm

[6] University College London (n.d.). Scholarly communication. Retrieved July 10, 2017 http://www.ucl.ac.uk/Library/scholarly-communication/index.shtml

[7] Mukherjee, B. (2009). Scholarly communication: A journey from print to web. Library Philosophy and Practice (e-journal). Paper 285. Retrieved July 10, 2017 http://digitalcommons.unl.edu/libphilprac/285 
[8] Rowlands, I., Nicholas, D., \& Huntington, P. (2004). Researchers' attitudes towards new journal publishing models. Learned Publishing, 17. Retrieved July 10, 2017 http://www.alpsp.org/volcont.htm

[9] Harnad, S. (1995). A subversive proposal. In Okerson, A., \& O’Donnell, J. (Eds.) Scholarly journals at the crossroads: A subversive proposal for electronic publishing. Washington, DC: Association of Research Libraries.

[10] Kronick, D. A. (1990). Peer review in 18th century scientific journalism. Journal of the American Medical Association, 263(10), 1321-1322.

[11] Cronin, B. (2005). The hand of science: Academic writing and its rewards. Lanham, MD: Scarecrow Press.

[12] Ziman, J. (2000). Real science. What it is, and what it means. Cambridge, UK: Cambridge University Press.

[13] Lamont, M. (2009). How professors think: Inside the curious world of academic judgment. Cambridge, MA: Harvard University Press.

[14] Alberts, B., Hanson, B., \& Kelner, K. L. (2008). Reviewing peer review. Science, 321(5885), 15.

[15] McClellan, J. E. (2003). Specialist control: The publications committee of the Academie Royal des Sciences (Paris) 1700-1793 (Transactions of the American Philosophical Society, v. 93). Philadelphia, PA: American Philosophical Society.

[16] Geisler, E. (2000). The metrics of science and technology. Westport, CT: Quorum Books.

[17] Eisenhart, M. (2002). The paradox of peer review: Admitting too much or allowing too little? Research in Science Education, 32(2), 241-255.

[18] Krampen, G., \& Montada, L. (2002). Wissenschaftsforschung in der Psychologie. Göttingen, Germany: Hogrefe.

[19] Hemlin, S., \& Rasmussen, S. B. (2006). The shift in academic quality control. Science, Technology, \& Human Values, 31(2), 173-198.

[20] Wessely, S., \& Wood, F. (1999). Peer review of grant applications: A systematic review. In F. Godlee \& T. Jefferson (Eds.), Peer Review in Health Sciences (pp. 14-31). London: BMJ Books.

[21] Guston, D. H. (2003). The expanding role of peer review processes in the United States. In P. Shapira \& S. Kuhlmann (Eds.), Learning from science and technology policy evaluation: Experiences from the United States and Europe (pp. 81-97). Cheltenham, UK: Edward Elgar.

[22] Biagioli, M. (2002). From book censorship to academic peer review. Emergences, 12(1), 11-45.

[23] Feist, G. J. (2006). The psychology of science and the origins of the scientific mind. New Haven, CT: Yale University Press.

[24] Hackett, E. J., \& Chubin, D. E. (2003). Peer review for the 21 st century: Applications to education research. Paper presented at the conference Peer Review of Education Research Grant Applications: Implications, Considerations, and Future Directions, Washington, DC.

[25] British Academy (2007). Peer review: The challenges for the humanities and social sciences. London: The Academy.

[26] Jayasinghe, U. W., Marsh, H. W., \& Bond, N. (2001). Peer review in the funding of research in higher education: The Australian experience. Educational Evaluation and Policy Analysis, 23(4), 343-364.

[27] Bakanic, V., McPhail, C., \& Simon, R. J. (1987). The manuscript review and decision-making process. American Sociological Review, 52(5), 631-642.

[28] Bornmann, L., \& Daniel, H.-D. (2008). The effectiveness of the peer review process: Interreferee agreement and predictive validity of manuscript refereeing at Angewandte Chemie. Angewandte Chemie International Edition, 47(38), 7173-7178.

[29] Fogg, L., \& Fiske, D. W. (1993). Foretelling the judgments of reviewers and editors. American Psychologist, 48(3), 293-294.

[30] Lock, S. (1985). A difficult balance: Editorial peer review in medicine. Philadelphia, PA: ISI Press.

[31] Petty, R. E., \& Fleming, M. A. (1999). The review process at PSPB: Correlates of interreviewer agreement and manuscript acceptance. Personality and Social Psychology Bulletin, 25(2), 188-203.

[32] Sternberg, R. J., Hojjat, M., Brigockas, M. G., \& Grigorenko, E. L. (1997). Getting in: Criteria for acceptance of manuscripts in Psychological Bulletin, 1993-1996. Psychological Bulletin, 121(2), 321-323.

[33] Zuckerman, H., \& Merton, R. K. (1971). Patterns of evaluation in science: Institutionalisation, structure and functions of the referee system. Minerva, 9(1), 66-100.

[34] Bornmann, L., Mutz, R., \& Daniel, H.-D. (2007). Row-column (RC) association model applied to grant peer review. Scientometrics, 73(2), 139-147.

[35] Marsh, H. W., \& Ball, S. (1991). Reflections on the peer review process. Behavioral and Brain Sciences, 14(1), 157-158.

[36] Poschl, U. (2004). Interactive journal concept for improved scientific publishing and quality assurance. Learned Publishing, 17(2), 105-113.

[37] Bornmann, L., \& Daniel, H.-D. (2005). Criteria used by a peer review committee for selection of research fellows: A Boolean probit analysis. International Journal of Selection and Assessment, 13(4), 296-303.

[38] Bornmann, L., Nast, I., \& Daniel, H.-D. (2008). Do editors and referees look for signs of scientific misconduct when reviewing manuscripts? A quantitative content analysis of studies that examined review criteria and reasons for accepting and rejecting manuscripts for publication. Scientometrics, 77(3), 415-432.

[39] Bakanic, V., McPhail, C., \& Simon, R. J. (1989). Mixed messages: Referees' comments on the manuscripts they review. Sociological Quarterly, 30(4), 639-654.

[40] Popper, K. R. (1961). The logic of scientific discovery (2nd ed.). New York: Basic Books.

[41] Bartley, W. W. (1984). The retreat to commitment (2nd ed.). La Salle, IL: Open Court.

[42] Editor to quit over hoax open-access paper. (2009). Nature, 459: 901.

[43] Sokal, A. D. (2008). Beyond the hoax: Science, philosophy and culture. Oxford, UK: Oxford University Press. 
[44] Goodman, S. N., Berlin, J., Fletcher, S. W., \& Fletcher, R. H. (1994). Manuscript quality before and after peer review and editing at Annals of Internal Medicine. Annals of Internal Medicine, 121(1), 11-21.

[45] Pierie, J. P. E. N., Walvoort, H. C., \& Overbeke, A. J. P. M. (1996). Readers' evaluation of effect of peer review and editing on quality of articles in the Nederlands Tijdschrift voor Geneeskunde. Lancet, 348(9040), 1480-1483.

[46] Roy, R. (1985). Funding science: The real defects of peer-review and an alternative to it. Science, Technology, \& Human Values, 52 (1), 73-81.

[47] Abelson, P. H. (1980). Scientific communication. Science, 209(4452), 60-62.

[48] Shatz, D. (2004). Peer review: A critical inquiry. Lanham, MD: Rowman \& Littlefield.

[49] Hoffmann, H., Joye, D., Kuhn, F., \& Métral, G. (2002). Der SNF im Spiegel der Forschenden: Synthesebericht. Neuchâtel, Switzerland: Schweizerischer Informations und Datenarchivdienst für die Sozialwissenschaften (SIDOS).

[50] Bedeian, A. G. (2003). The manuscript review process: The proper roles of authors, referees, and editors. Journal of Management Inquiry, 12(4), 331-338.

[51] Bertout, C., \& Schneider, P. (2004). Editorship and peer-review at A\&A. Astronomy \& Astrophysics, 420, E1-E14.

[52] Overview: Nature's peer review trial. (2006). Nature. Retrieved August 14, 2017 www.nature.com/nature/peerreview/debate/nature05535.html

[53] Gibson, M., Spong, C. Y., Simonsen, S. E., Martin, S., \& Scott, J. R. (2008). Author perception of peer review. Obstetrics and Gynecology, 112(3), 646-651.

[54] Hornbostel, S., \& Olbrecht, M. (2007). Peer Review in der DFG: Die Fachkollegiaten (iFQ-Working Paper No. 2). Bonn, Germany: Institut für Forschungsinformation und Qualitätssicherung.

[55] Publishing Research Consortium. (2008). Peer review in scholarly journals: Perspective of the scholarly community: An international study. Bristol, UK: The Consortium.

[56] Cole, S., Cole, J. R., \& Simon, G. A. (1981). Chance and consensus in peer-review. Science, 214(4523), 881-886.

[57] Young, S. N. (2003). Peer review of manuscripts: Theory and practice. Journal of Psychiatry \& Neuroscience, 28(5), 327-330.

[58] Frey, B. S. (2003). Publishing as prostitution? Choosing between one's own ideas and academic success. Public Choice, 116(1-2), 205-223.

[59] Gupta, V.K. (2017). Citation errors in scholarly communication: A critical evaluation. Indian Journal of Library and Information Science: An International Journal, 11(2), 228-233.

[60] Bornmann, L. (2011). Scientific peer review. Annual Review of Information Science and Technology, 45 (1), 199245.

[61] Ehses, I. (2004). By scientists, for scientists. The Deutsche Forschungsgemeinschaft (DFG, German Research Foundation) and how it functions. B.I.F. Futura, 19, 170-177.

[62] National Academy of Sciences. (2006). Beyond bias and barriers: Fulfilling the potential of women in academic science and engineering. Washington, DC: The National Academies Press.

[63] Asano, M., Mikawa, K., Nishina, K., Maekawa, N., \& Obara, H. (1995a). The accuracy of references in Anaesthesia. Anaesthesia: Journal of the Association of Anaesthetists of Great Britain and Ireland, 50(12), 10801082.

[64] Asano, M., Mikawa, K., Nishina, K., Maekawa, N., \& Obara, H. (1995b). Improvement of the accuracy of references in the Canadian Journal of Anaesthesia. Canadian Journal of Anaesthesia, 42(5), 370-372.

[65] Pandit, I. (1993). Citation errors in library literature: A study of five library science journals. Library \& Information Science Research, 15(2), 185-198.

[66] Onwuegbuzie, A.J., Frels, R.K., \& Slate, J.R. (2010). Editorial: Evidence-based guidelines for avoiding the most prevalent and serious APA error in journal article submissions- the citation errors. Research in the Schools, 17(2), $1-24$.

\footnotetext{
About the Author

Vishnu Kumar Gupta, presently serving as Librarian at Banasthali University's Department of Bioscience and Biotechnology and is research fellow in the Department of Library and Information Science in the same University. He received his MLIS from University of Rajasthan, Jaipur in 2002; scored highest marks in India in UGC's National Eligibility Test; and has extensive experience managing distinguished information services in college and university libraries.
}

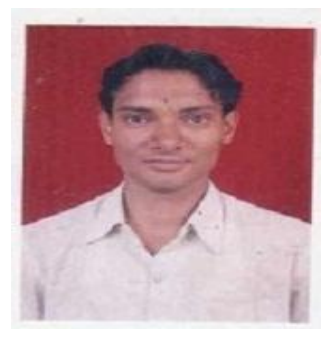

